\title{
Social Capital and Access to Bank Financing: The Case of Chinese Entrepreneurs*
}

\author{
Oleksandr Talavera \\ University of East Anglia \\ Lin Xiong \\ The Robert Gordon University \\ Xiong Xiong \\ Tianjin University \\ 8 October, 2010
}

"Standard disclaimer applies. We thank participants of the Society of the Study of Emerging Markets Euroconference for valuable comments and suggestions. We are grateful to the Royal Society of Edinburgh and the National Natural Science Foundation of China for financial support. Corresponding author: Oleksandr Talavera, School of Economics, University of East Anglia, Norwich, NR4 7TJ, UK, Tel: +44 1603-59-3415, e-mail: s.talavera@uea.ac.uk. 
SOCIAL CAPITAL AND ACCESS TO BANK FINANCING: THE CASE OF CHINESE ENTREPRENEURS

\begin{abstract}
This paper studies the effects of social capital on access to bank financing. Based on a Chinese nationwide survey our analysis suggests that entrepreneurs who spend more time on social activities are more likely to obtain a loan from commercial banks. In addition, we find that membership of political parties is an important determinant of state bank financing. Finally, our data reveals some evidence of substitutability between various types of social capital. To get a loan from a specific type of bank, an entrepreneur should access the relevant social network. The results of our analysis are robust to a number of specification checks.
\end{abstract}

Keywords: China, social capital, entrepreneurs.

JEL: G21, L26. 


\section{Introduction}

It is hard to undervalue the role of social capital for entrepreneurs. Besides having an idea, it is necessary to interact with other market agents to develop the business. For example, not only relevant experience but also availability of existing links in particular areas might decrease costs of production and promote sales. Furthermore, links to financial institutions are particularly important in the early stages of business development as they reduce obstacles in external financing, usually faced by young and small firms.

The finance and entrepreneurship literature has long suggested the existence of financial frictions, implying that entrepreneurs are unable to receive funding to finance their business ideas (e.g. Evans and Jovanovic, 1989). Recently, a number of studies have investigated how access to social capital facilitates access to finance for establishing companies and subsequent performance. For example, Uzzi (1999) argues that social embeddedness facilitates the transfer of private information between lenders and borrowers. Complementary to the public knowledge (e.g. annual reports) banks also receive access to non-standard information (e.g. unpublished innovations). ${ }^{1}$ Additionally, entrepreneurs with larger and more diverse sets of contacts might have more productive enterprises which result in a better credit rating (Barr, 2000). Finally, informal links to borrowers also create value for a bank which reduces transaction costs related to writing a contract and allows them to retain clients (Boot, 2000).

Membership in social networks is particularly important in developing and emerging market countries. The operating environments in these countries are plagued by corruption, lack of human and material resources, poor management, and inefficient judicial systems (Biggs and Shah, 2006). In these circumstances entrepreneurs have to rely on social capital and join multi-level social networks. For instance, Honig (1998) finds that more frequent church attendance by Jamaican entrepreneurs leads to an increase in the profitability of their businesses. Notably, social networks could also be shared by family members or even inherited. Djankov et al. (2006) claim that Chinese entrepreneurs are more likely to have family members who are also entrepreneurs.

\footnotetext{
${ }^{1}$ See also Zuckerman (1999).
} 
In the investigation of how social capital affects entrepreneurship, the case of China is particularly interesting. China's economy has grown rapidly over the past three decades. At the same time, it has undergone a fundamental change, from complete reliance on state-owned and collective enterprise to a mixed economy where private enterprises also play a strong role. Private enterprises were not officially recognized until 1988. By 1998, the private sector had grown to about $33 \%$ of gross domestic product, making it second to the state enterprise sector in economic importance. ${ }^{2} \mathrm{~A}$ constitutional amendment in 1999 formally recognized the importance of the private sector to the economy, thereby laying the foundation for the private sector to emerge from the shadows and play a prominent role in China's future development. The speech by President Jiang Zemin in July 2001 further contributed to a significant improvement in the climate for private enterprise in China, which extended membership of the Communist Party of China (CPC) to the owners of private businesses. ${ }^{3}$ Officials and entrepreneurs interpreted this development as an important elevation in the status of the private sector.

This paper contributes to the stream of entrepreneurial literature in a number of ways. First, the analysis of China's private sector has concentrated on the dramatic surge in foreign direct investment and has paid little attention to private enterprises and entrepreneurship. This paper attempts to understand the domestic private sector and address the question: what is the impact of social capital on financial obstacles faced by Chinese entrepreneurs? Second, we distinguish between two types of social networks. We hypothesize that membership of the CPC might facilitate access to state bank financing, while affiliations with business associations might be important for commercial bank loan decisions.

We evaluate the role of social capital on bank loan financing based on extensive nationwide surveys on Chinese private enterprises across 31 provinces in 2004 and 2006. Using pooled data of about 270 small companies we find that membership in business associations increases the probability of having a loan by $14.8 \%$. Similarly, this result is also observed for loans from local commercial banks, while the effect appears to be statistically insignificant for state-owned banks. In contrast owner's

\footnotetext{
${ }^{2}$ See Chinese Statistics Yearbook, 1999.

${ }^{3}$ See the speech made by Jiang Zemin, General Secretary of the Central Committee of the CPC, at the meeting celebrating the Eightieth Anniversary of the Founding of the CPC.
} 
membership in the CPC is positive (10.2\%) and significant for state banks only. Finally, hours spent on hospitality and networking positively affect the probability of having loans from commercial banks. One hour per day spent at social events increases the probability of having a loan by $3.7 \%$.

These findings have a number of broader implications. First, government-supported business associations indeed facilitate access to external financing of Chinese entrepreneurs. Second, membership in dominant political parties substantially decreases the degree of financial constraints faced by entrepreneurs in environments with underdeveloped financial markets. Third, we find some evidence of substitutability between various types of social capital. To get a loan from a specific type of bank, an entrepreneur should access the relevant social network.

The rest of the paper is organized as follows. Section 2 briefly overviews entrepreneurship in China. Section 3 presents the model and describes our data. Section 4 provides the empirical results and Section 5 concludes.

\section{Entrepreneurship in China}

The phenomenon of entrepreneurship in China is quite controversial. This group of business agents could share opinions which contradict the centrally imposed political policies. However, in line with Schumpeter's view, entrepreneurs produce innovations and technological improvements, which are crucial for the development of any country. Starting from the 1980s, the CPC has implemented market reforms which has led to the emergence and rapid development of the private sector.

Private enterprises first emerged in rural areas and in sectors such as trade and service, where there were a limited number of large state enterprises and market opportunities for private entrepreneurs. The scope of private sector activities then gradually expanded, as their legal and organizational framework, presence in various sectors and geographic distribution increased. Now the private sector is important and the most dynamic component of the domestic economy. There were about 9.7 million enterprises registered in the State Industry and Commercial registration Bureau until the end of 2008, of which $68 \%$ were private enterprises (China Commerce Yearbook, 2009). Between 2002 and 2007, the number of private 
enterprises grew at an average annual rate of $18 \%$, employment in private enterprises grew by $9 \%$ and output grew at $49 \%$ (Table 1 ).

\subsection{Sources of Financing}

The node of financing of Chinese entrepreneurs resembles patterns in other emerging markets. Substantial start-up funds come from own savings and gifts from family and friends. Furthermore, some ventures acquire financing from private credit agencies $^{4}$ (minjian jiedai) and banks ${ }^{5}$. According to a 2006 survey conducted by the All-China Federation of Industry and Commerce (ACFIC) and the State Administration for Industry and Commerce (SAIC), 67\% of entrepreneurs started their businesses by relying exclusively on self-financing. Other similar surveys (Webster and Taussig, 1999; Gregory et al., 2000) indicate that initial funding from financial institutions played only a minor role for Chinese private firms and that startup firms in other transitional economies have better access to bank loans. More than $90 \%$ of the initial capital in Chinese firms came from the principal owners, the startup teams and their families (Gregory et al., 2000). By contrast, about two-thirds of start-ups in the Czech Republic receive banks loans (Webster and Taussig, 1999).

In the case of working capital and additional (post-start-up) investment for expansions, $86 \%$ of the private enterprises surveyed suggested difficulty in accessing bank loans. At the end of 2007, the share of loans from banks and other financial institutions outstanding to the private enterprises was less than $1.5 \%$ of total lending, although it has shown an increasing trend over the past decade (Figure 1). Compared with the sector's contribution to employment and output (see Table 1), the share of lending to the private sector is low.

The inability to meet collateral requirements is the most frequent reason for entrepreneurs finding it difficult to obtain bank loans, which is in line with the result found in Gregory and Tenev (2001). Most bank loans in China are backed by collateral and the only type of collateral acceptable to many banks is land or

\footnotetext{
${ }^{4}$ It consists of individual lenders or non-delegated monitors such as pawnbrokers, moneylenders and institutions that operate without state charters (Tsai, 2004; Allen et al., 2005).

${ }^{5}$ The Chinese banking sector is dominated by four state-owned banks, namely the Agricultural Bank of China ( $A B C$ ), the Industrial and Commercial Bank of China (ICBC), the Bank of China (BOC) and the People's Construction Bank of China ( $\mathrm{PCBC}$ ). There are also several other minor players in the sector, including three policy banks (Export-import Bank, Agricultural Development Bank and State Development Bank), commercial banks (e.g. the Bank of Communications), and regional banks such as city banks.
} 
buildings (Cousin, 2006). Movable assets are rarely used as security due to the highly restrictive secured financing lending system; inventory and receivables cannot be used as collateral under Chinese Security Law (Ayyagari et al., 2010).

By contrast, private credit agencies rarely require collateral or guarantees. A survey, conducted by Zhang et al. (2002), estimates that $84 \%$ of all informal lending in the Guangdong province is based on personal credit without collateral. The informal lenders that do require collateral are more lenient than banks in the types of collateral that they require, including oxen or personal assets such as motorcycles, and are more willing to renegotiate loan terms and contracts (Tsai 2002; Ayyagari et al., 2010). In line with this, the ACFIC and the SAIC survey suggest that more than one-third of Chinese private firms borrow from private credit agencies for start-up capital. Allen et al. (2005) found that financing from private credit agencies, instead of banks, is the most important channel during the firm's growth period.

\subsection{Social Networking in the Chinese Context}

Studies show that the Chinese hold a collectivist instead of an individualist culture (McGrath et al., 1992). According to Confucianism, individuals are fundamentally social or relational beings and are less important than they are in Western society (Redding, 1991). Cooperation across society in China relies upon social networking for the construction of dependable personal relations (Farh et al., 1998). Furthermore, business behavior revolves around this form of dependent personal relations, or guanxi. Guanxi bonds two persons through the exchange of favors rather than through sentiment. The guanxi relationship does not have to involve friends. Instead, the relationship is basically utilitarian rather than emotional (Alston, 1989).

In China, guanxi is essential for obtaining scarce resources as well as for dealing with the bureaucratic maze (Brunner et al., 1989). The use of social networks may gain access to goods and services that are otherwise difficult or impossible to come by. China was a shortage economy, and the ability to secure such factor inputs as suppliers of raw materials or manufactured goods, capital and even labor and managerial staff was a major challenge for every enterprise (Murphy et al., 1992). Unlike in state-owned enterprises, private entrepreneurs have to source everything 
by themselves and to work hard building up guanxi to gain access to the inputs (Tsang, 1994; Zhao and Aram, 1995).

During the past three decades, marked improvements have been achieved in transforming the economy into being market-oriented and the distribution system for production inputs, labor market and capital market are much less rigid than before. The literature still implies that social networking is common among Chinese entrepreneurs, especially among those in the private sector and that it has positive effects on outcome variables.

Zhao and Aram (1995) affirmed the importance of entrepreneurial networking by interviewing managers of six young technology-oriented firms in China. Managers in the three high-growth firms reported greater range and intensity of business networking than managers of three low-growth firms. Xin and Pearce (1996), using a group of business executives in mainland China, further substantiated the importance of guanxi for business executives in China. It is a powerful mechanism by which those executives obtain resources, information or support in business situations. A more recent study by Batjargal and Liu (2002) reviews 158 venture capital investment decisions in Beijing and Shanghai and argues that the social capital of entrepreneurs has an enhancing effect on investment selection decisions of venture capitalists (to invest versus not to invest), and main effects of social capital on investment process decisions such as venture valuation, investment delivery speed and contractual warrants/provisions.

In addition to building up individual social networks, Chinese entrepreneurs can become a member of the ACFIC ${ }^{6}$, which allows entrepreneurs to build credibility, gain advice, financing and customer access, build a positive image and to increase the speed of know-how and technology transfers. The ACFIC ${ }^{7}$, established in 1953,

\footnotetext{
${ }^{6}$ The major functions of the ACFIC include: building communication channels between the government and private sector; assisting government in managing private sector; participating in political consultation of national policies and strategies in politics, economy and social affairs; guiding its members in technological innovation, management and culture for enhanced competitiveness and capability in achieving sustainable development; representing the legitimate rights of its members and extending their proposals and requirements to government; providing members with services in training, financing, technology, legal consultation and information, and resolving the difficulties and problems they are facing; building closer relations with commercial and industrial counterparts overseas; and helping members to go overseas for business opportunities and contributing to China's opening-up program.

${ }^{7}$ The ACFIC had 3,130 local branches at provincial level, 23,993 branches at urban district, community and village levels and 10,337 trade groups by the end of 2008 .
} 
is an organization composed of industrialists and businessmen under the leadership of the CPC. The ACFIC had 2.33 million registered members nationwide at the end of 2008. Before the economic reform began in 1979, the majority of ACFIC members were those engaged in various types of economic and commercial activities. Over the past three decades, with the rapid development of the private sector, current ACFIC memberships are largely held by entrepreneurs in the private sector.

\section{Empirical Implementation}

\subsection{Test Design}

To quantify the access to external financing by Chinese entrepreneurs we use a variant of an empirical specification proposed by earlier researchers. The main difference in our approach is the introduction of four measures of social capital. Second, we investigate the effect of social capital on the financing of state-owned banks versus commercial banks. Our baseline model takes the following form:

$$
\operatorname{Prob}\left(\operatorname{Loan}_{i t}=1\right)=\Lambda\left(\alpha+\beta \text { Social } \text { Capital }_{i t}+Z_{i t} Y\right)
$$

where loan equals one if a firm received a loan and zero otherwise; social capital is one of four measures: hours of hospitality activities, expenses related to hospitality activities, membership in business associations, and membership in CPC; and $Z$ is a vector of firm and individual specific characteristics.

Vector $Z$ combines variables that characterize the creditworthiness of the firm from the bank's viewpoint. In general, the decision to grant a loan and its contractual conditions crucially depends on the associated risk and the business reputation. These, however, are not directly measured in our data and we therefore proxy them by the firm's age, collateral, firm's size and profitability. The latter variable is likely to be simultaneously determined with the dependent variable because loans might be used for investments, consequently leading to higher profitability. To address this issue we employ lagged return on sales as a measure of performance. Finally, we include industry and year 2006 dummy variables.

\subsection{Data}

In our empirical investigation we use manufacturing firm-level data extracted from a nationwide sample survey of privately owned enterprises and their owners. The 
survey samples from the universe of registered businesses in the private sector and was conducted every two years from 1991 to 2006 by the ACFIC and the SAIC. The major content includes firms' organizational and financial characteristics, managerial characteristics, social-economic background of enterprise owners; composition of employees and employee-employer relations; self-assessment by owners; and political and social participation. The analysis in this paper is conducted using data pooled over 2004 and 2006 due to the homogeneity of the data. More than 4,000 questionnaires were distributed each year with 3,012 returned in 2004 and 3,837 returned in 2006.

Both the overall design of our dataset and the exact wording of the loan financing question dictate a specific procedure for selecting a sample that would be appropriate for the analysis of financial constraints faced by Chinese entrepreneurs. To ensure a focus on entrepreneurs, we immediately keep only those firms where the largest owner is an individual. Then, we restrict the sample to the firms where the individual is also the manager. By following these steps we keep only individuallyowned firms with no separation of ownership and management. Finally, we keep only those companies who reported difficulties in obtaining loans. This screening allows us to concentrate only on those entrepreneurs who have positive demand for external financing.

Basic characteristics of the firms sampled are summarized in Table 2. Notably, while $45 \%$ of companies reported that they have bank loans, only $5 \%$ are financed from both types of banks. Furthermore, state bank financing slightly prevails (28\%) over commercial bank financing (22\%). It appears that business ventures are mostly financed by own and family savings, and informal loans from friends and pawnbrokers. Share of female managers is quite low and equals $14 \%$. Finally, an average entrepreneurial Chinese firm is about seven years old, but has a $12 \%$ profit margin.

Table 3 summarizes the social capital data by type of banks that provide loan financing. The banks are divided in two groups, namely state and commercial. The first group consists of the four largest banks which cover major sectors of Chinese economy: the Agricultural Bank of China $(A B C)$, the Industrial and Commercial Bank of China (ICBC), the Bank of China (BOC) and the People's Construction Bank of 
China (PCBC). These are the largest banks with each having more than 10,000 branches all over the country (Chan et al., 2007). In contrast, commercial banks are substantially smaller and usually operate in a particular region.

Note that the owners of firms with access to bank financing are more likely to be members of business associations. Moreover, there are no differences for firms with and without bank financing when we compare statistics on hospitality expenses. Overall - while providing some support for the importance of social capital - a simple descriptive analysis of constraints in external financing fails to establish a clear pattern. Analysis in the multivariate framework that accounts for confounding factors is needed. The next section describes the econometric strategy that we employ to investigate the effects of social capital on the access to bank financing.

\section{Results Discussion}

Prior to presenting our findings it is useful to point out that all models have a binary dependent variable. That is why we employ logit methodology with robust standard errors. Even though our data covers two years, 2004 and 2006, we are not able to identify firms in both year and have run pooled regression. Marginal effects around mean points are reported in Tables $3-7 .^{8}$

Evidence that social capital decreases degrees of financial constraints is the same for all types of banks is not robust. We can see this from Table 4, which reports effects of "hospitality time" on loan availability. Column 1 reports results for the availability of a loan from any bank. As anticipated, social capital proxy has a positive and significant but statistically insignificant effect. One extra hour per day, spent on social activities increases the likelihood of a loan by $2.3 \%$. As reported in Columns 2 and 3 the effect of "hospitality hours" is stronger and statistically significant for the likelihood of obtaining a loan from commercial banks (3.7\%). Another interesting finding is the positive and strongly significant effect of size of companies, measured by the natural logarithm of number of employees, on the likelihood of obtaining a loan. The data reveals that larger companies have much lower obstacles for receiving external financing. This result is in line with Schiffer and Weder (2001) who find that larger firms report lower financing obstacles. The higher financing obstacles

\footnotetext{
${ }^{8}$ We have also estimated marginal effects around median points and received quantitatively similar results.
} 
faced by small firms are observed in both developed and developing countries (Berger and Udell, 1998; Galindo and Schiantarelli, 2003), which also confirms the theory's predictions (Beck and Demirgüç-Kunt, 2006). In a world with fixed transaction costs and information asymmetries, small firms with demand for smaller loans face higher transaction costs and face higher risk premiums since they are typically more opaque and have less collateral to offer (Beck et al., 2006). Our data also reveals that collateral measures positively affect the probability of obtaining loans from commercial banks. Finally, the gender of the entrepreneur does not play an important role in the loan application decision making process. This is an interesting finding as Muravyev et al. (2009) report that compared to male-managed counterparts, female-managed firms are less likely to obtain a bank loan. In addition, they suggest that female entrepreneurs are charged higher interest rates when loan applications are approved.

The estimation results, with hospitality related expenses as the second measure of social capital, are reported in Table 5. However, the effects of social capital are positive but not statistically different from zero. This evidence might suggest that the costs for hospitality also included indirect hospitality-related expenses, such as advertising or participation in expositions. The effects of the other variables follow the pattern of Table 4.

Table 6 depicts the estimation results for specification (1) with membership in business associations as a proxy for social capital. Overall, this variable has an effect on loan availability from any bank: membership in business association increases the probability of obtaining a loan from any bank by about $15 \%$. This outcome is likely to be driven by commercial banks' loan decision makers. This link could be explained by the closer relationship of relatively small commercial banks with business associations.

Finally, Table 7 provides the results with China Communist Party membership as our fourth measure of social capital. We hypothesize that the party members could interact and build contacts during Communist Party meetings. For example, entrepreneurs could meet bankers and discuss business issues before or after meetings. Interestingly, the membership increases the likelihood of obtaining a loan by $9.2 \%$ (see Column 1 of Table 7 ). This effect is stronger and statistically significant 
for the likelihood of having a loan from a state bank (10.2\%) as reported in Column 2 of Table 7. This link could also be explained by indirect effects of performance. Better performing entrepreneurs could become members of the CPC. However, we do not observe significance of Communist Party membership for loan availability in commercial banks.

Overall, out data provides evidence of the importance of social capital for the loan application procedure. This outcome confirms findings of finance literature (e.g. DiMaggio and Louch, 1998; Uzzi, 1999) that bank-firm ties are more critical to lending markets than classical theory suggests. The coefficients by social capital measure are positive and statistically significant in the majority of cases. Importantly, our estimates also reveal entrepreneurs should be bank-type oriented while investing in social capital. For example, membership in business associations plays a role for commercial banks loan applications, while membership in the CPC facilitates access to loan financing from state banks.

\section{Conclusions}

This paper investigates the relationship between social capital and the access to bank financing in China. We use extensive national survey data on Chinese private enterprises in 2004 and 2006. The analysis is based on several specifications of logit model with robust standard errors. Four different measures of social capital are employed: hours of hospitality activities, expenses related to hospitality activities, membership in business associations and membership in CPC.

The results of empirical analysis suggest that social capital plays an important role in Chinese entrepreneurs' access to bank financing. Furthermore, types of social network matter to the access of loans from different banks. Communist Party membership has a positive effect on the application for loans from state banks. Spending more time on hospitality and membership in business associations is important for getting loans from commercial banks. The business associations can assist private enterprises with loan applications: for example, they recommend good enterprises to banks with a view to reducing the efficiency losses associated with informational asymmetry. The results of this study lead to the preliminary conclusion 
that private entrepreneurs should not be content with limited social capital and they are advised to explore and strengthen a broad range of network relations.

Improving private entrepreneurs' access to external finance also requires the government to create incentives for banks to lend to and invest in private enterprises. With state-owned banks dominating the Chinese financial sector, strengthening the profit incentives for these banks would have a major impact on improving private firms' access to bank loans. Commercial banks are less likely to be influenced by political considerations and more likely to be profit-oriented. With greater access to external finance, China's private enterprises will continue to play an important role in the growth and transformation of the Chinese economy. 


\section{References}

Allen, F., Qian J., and M. Qian. "Law, Finance, and Economic Growth in China." Journal of Financial Economics 77, 2005: 57-116.

Alston, J.P. "Wa, Guanxi, and Inhwa: Managerial Principles in Japan, China, and Korea." Business Horizons 32, no.2, 1989: 26-31.

Ayyagari, M., Demirguc-Kunt A. and Maksimovic V. "Formal Versus Informal Finance: Evidence from China." Review of Financial Studies, 23, no.8, 2010: 30483097.

Barr, A. "Social Capital and Technical Information Flows in the Ghanaian Manufacturing Sector." Oxford Economic Papers 52, no.3, 2000: 539-59.

Batjargal, B. and Liu M. M. “Entrepreneurs' Access to Private Equity in China: The Role of Social Capital." William Davidson Institute Working Paper 453, University of Michigan, 2002.

Beck, T. and Demirgüç-Kunt, A. "Small and Medium-size Enterprises: Access to Finance as a Growth Constraint." Journal of Banking \& Finance, 30, 2006: 29312943.

Beck, T., Demirgüç-Kunt, A., Laeven, L. and Maksimovic, V. "The Determinants of Financing Obstacles." Journal of International Money and Finance, 25, no.6, 2006: 932-952.

Berger, A. N. and Udell, G. F. "The Economics of Small Business Finance: The Role of Private Equity and Debt Markets in the Financial Growth Cycle." Journal of Banking and Finance, 22, 1998: 613-673.

Biggs, T. and Shah, M. K. "African SMEs, Networks, and Manufacturing Performance." Journal of Banking and Finance 30, no.11, 2006: 3043-3066.

Boot, A.W.A. "Relationship Banking: What Do We Know?" Journal of Financial Intermediation 9, no.1, 2000: 7-25.

Brunner, J.A., Chen, J., Sun C., and Zhou, N. "The Role of Guanxi in Negotiations in the Pacific Basin.” Journal of Global Marketing 3, no.2, 1989:7-23.

Chan, K.C; Fung, H. G and Liu, Q. F. China's Capital Markets: Challenges from WTO Membership. Cheltenham: Edward Elgar, 2007.

Cousin, V. Banking in China. New York: Palgrave Macmillan, 2006.

DiMaggio, $\mathrm{P}$ and Louch, $\mathrm{H}$. "Socially Embedded Consumer Transactions: For What Kinds of Purchases Do People Most Often Use Networks." American Sociological Review, 63, 1998: 619-637.

Djankov, S., Qian, Y., Roland, G. and Zhuravskaya, E. "Who are China's Entrepreneurs?" American Economic Review 96, no.2, 2006: 348-352. 
Evans, D. S. and Jovanovic, B. "An Estimated Model of Entrepreneurial Choice Under Liquidity Constraints." Journal of Political Economy 97, no.4, 1989:808-27.

Farh, L., Tsui, A., Xin, K and Cheng, B. "The Influence of Relational Demography and Guanxi: The Chinese Case." Organization Science, 9. no.4, 1989: 471-488.

Galindo A. and Schiantarelli, F. "Determinants and Consequences of Financial Constraints Facing Firms in Latin America: An Overview", In: Galindo A. and Schiantarelli F. (Eds), Credit Constraints and Investment in Latin America. Washington: Inter-American Development Bank, 2003: 1-22

Gregory, N., and Tenev. S. "The Financing of Private Enterprise in China." Finance and Development, 38, 2001: 14-17.

Gregory, N., Tenev. S. and Wagle D. M. China's Emerging Private Enterprises: Prospects for the New Century. Washington: International Finance Corporation, 2000.

Honig, B. "What Determines Success? Examining the Human, Financial, and Social Capital of Jamaican Microentrepreneurs." Journal of Business Venturing 13, no.5, 1998: 371-394.

McGrath, R.G., MacMillan, I.C., Yang, E.A., and Tsai, W. "Does Culture Endure, or is it Malleable? Issues for Entrepreneurial Economic Development." Journal of Business Venturing 7, 1992: 441-458.

Muravyev, A., Schafer D., and Talavera, O. "Entrepreneurs Gender and Financial Constraints: Evidence from International Data." Journal of Comparative Economics, 37. no.2, 2009: 270-286

Murphy, K.M., Shleifer, A., and Vishny, R.W. "The Transition to a Market Economy: Pitfalls of Partial Reform." Quarterly Journal of Economics 107, no.3, 1992: 889-906.

Redding, S.G. "Culture and Entrepreneurial Behaviour among the Overseas Chinese." In Berger, B. (ed). The Culture of Entrepreneurship. San Francisco: ICS, pp. 137-156, 1991.

Schiffer, M. and Weder, B. Firm Size and the Business Environment: Worldwide Survey Results. Discussion Paper No. 43, International Finance Corporation, Washington, DC, 2001.

Tsai, K. Back-Alley Banking: Private Entrepreneurs in China. Ithaca, NY: Cornell University Press, 2002.

Tsai, K. "Imperfect Substitutes: The Local Political Economy of Informal Finance and Microfinance in Rural China and India." World Development, 32, 2004:1487-507.

Tsang, E.W.K. "Threats and Opportunities Faced by Private Businesses in China." Journal of Business Venturing 9, 1994: 451-468. 
Uzzi, B. "Embeddedness in the Making of Financial Capital: How Social Relations and Networks Benefit Firms Seeking Financing." American Sociological Review 64, no.4, 1999: 481-505.

Webster, L. and Taussig M. "Vietnam's Undersized Engine: A Survey of 95 Larger Private Manufacturers." MPDF Private Sector Discussion Papers, World Bank, Washington, D.C, 1999.

Xin, K. and Pearce, J. "Guanxi: Connections as Substitutes for Formal Institutional Support." Academy of Management Journal, 39, 1996: 1641-1658.

Zhang, J., Yuan Z. and Lin P. "From Interpersonal Credit to Unregulated, PrivateGoverned Financial Institutions: Formats and Pricing Mechanisms of Informal finance." Journal of Financial Research, 268, 2002: 101-9.

Zhao, L.M and Aram, J. D. "Networking and Growth of Young Technology-Intensive Ventures in China." Journal of Business Venturing 10, 1995: 349-370

Zuckerman, E. W. "The Categorical Imperative: Securities Analysts and the Illegitimacy Discount." The American Journal of Sociology 104, no.5, 1999: 13981438. 
Figure 1: Loans from Financial Institutions to Private Enterprises, 1995-2007

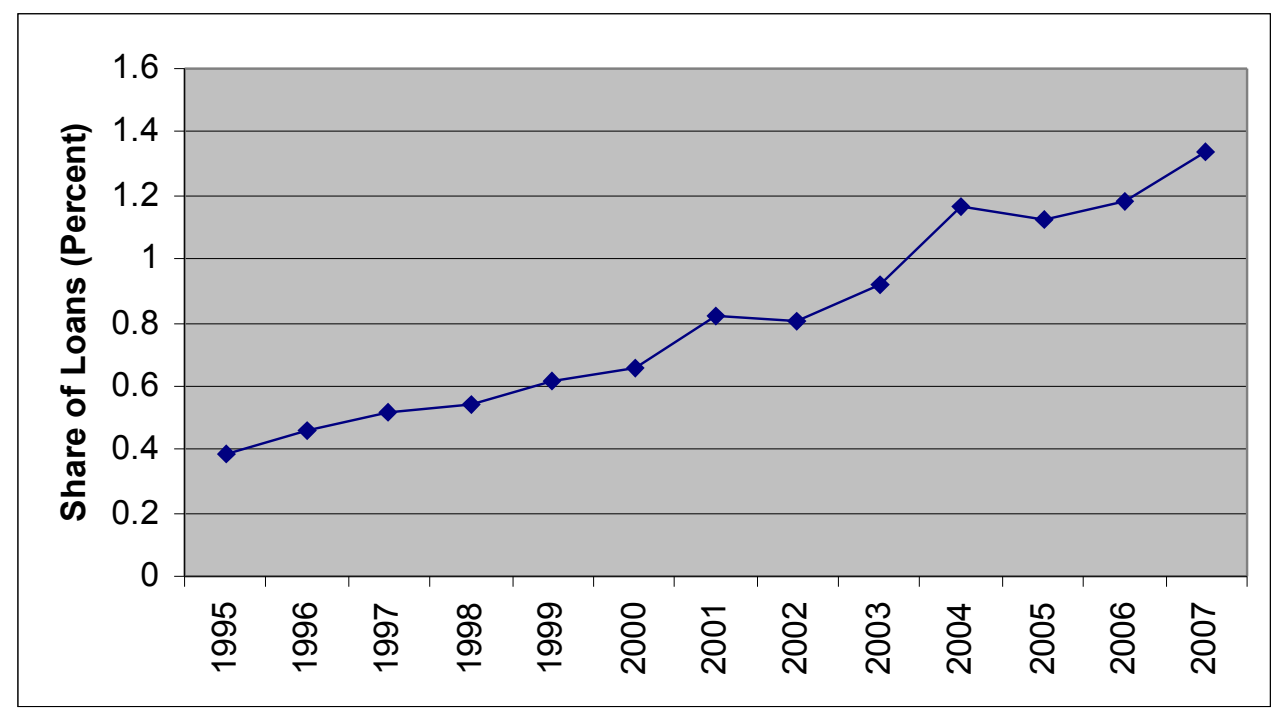

Source: China Statistical Yearbook, 1996-2008 
Table 1: Private Enterprise Development, 2002-2007

\begin{tabular}{ccccccc}
\hline & \multicolumn{2}{c}{ Enterprises } & \multicolumn{2}{c}{ Employment } & \multicolumn{2}{c}{ Output $^{*}$} \\
\cline { 2 - 7 } Year & $\begin{array}{c}\text { Number } \\
(10,000)\end{array}$ & $\begin{array}{c}\text { Growth } \\
\text { (percent) }\end{array}$ & $\begin{array}{c}\text { Number } \\
(10,000)\end{array}$ & $\begin{array}{c}\text { Growth } \\
\text { (percent) }\end{array}$ & $\begin{array}{c}\text { Value } \\
\text { (100 } \\
\text { million }\end{array}$ & $\begin{array}{c}\text { Growth } \\
\text { (percent) }\end{array}$ \\
\hline 2002 & 263.83 & & 8152.2 & & 12950.9 & \\
2003 & 328.72 & 24.6 & 8935.7 & 9.6 & 20980.2 & 62.0 \\
2004 & 402.41 & 22.4 & 9604.4 & 7.5 & 35141.3 & 67.5 \\
2005 & 471.95 & 17.3 & 10724.6 & 11.7 & 47778.2 & 36.0 \\
2006 & 544.14 & 15.3 & 11746.0 & 9.5 & 67239.8 & 40.7 \\
2007 & 603.05 & 10.8 & 12750.0 & 8.5 & 94023.3 & 39.8 \\
\hline Average & & 18.1 & & 9.4 & & 49.2 \\
\hline
\end{tabular}

Note: "Output" refers to gross industrial output value.

Source: China Statistical Yearbook, 2003-2008 
Table 2: Descriptive Statistics and Definitions.

\begin{tabular}{|c|c|c|c|}
\hline Variable & Definition & mean & s.d. \\
\hline Loan & 1 if the firm has a loan, 0 otherwise & 0.450 & 0.498 \\
\hline State Bank Loan & $\begin{array}{l}1 \text { if the firm has a loan from a state bank, } 0 \\
\text { otherwise }\end{array}$ & 0.283 & 0.451 \\
\hline $\begin{array}{l}\text { Commercial Bank } \\
\text { Loan }\end{array}$ & $\begin{array}{l}1 \text { if the firm has a loan from a commercial bank, } 0 \\
\text { otherwise }\end{array}$ & 0.223 & 0.417 \\
\hline $\begin{array}{l}\text { Hours for } \\
\text { Networking }\end{array}$ & Hours spent on hospitality/networking activities & 3.466 & 1.793 \\
\hline Hospitality Expenses & $\begin{array}{l}\text { The natural logarithm of annual hospitality } \\
\text { expenses measured in } 10,000 \text { RMB }\end{array}$ & 0.966 & 0.795 \\
\hline $\begin{array}{l}\text { Business } \\
\text { Associations }\end{array}$ & $\begin{array}{l}1 \text { if firm is a member of Business Associations, } 0 \\
\text { otherwise }\end{array}$ & 0.751 & 0.433 \\
\hline Communist & $\begin{array}{l}1 \text { if manager is a member of the Communist Party } \\
\text { of China, } 0 \text { otherwise }\end{array}$ & 0.331 & 0.471 \\
\hline ROS & Return on Sales & 0.124 & 0.183 \\
\hline Firm Age & Firm age in years & 7.089 & 4.552 \\
\hline Log(Labor) & The natural logarithm of number of employees & 3.695 & 0.937 \\
\hline Collateral & $\%$ fixed assets in total assets & 45.632 & 29.567 \\
\hline Female & 1 if entrepreneur is female, 0 otherwise & 0.138 & 0.345 \\
\hline
\end{tabular}

Note: Number of observations is 269 . 
Table 3: Descriptive Statistics of Social Capital Measures by Types of Financing.

Panel A: Loans from all types of banks

\begin{tabular}{|c|c|c|c|c|c|c|c|}
\hline & \multicolumn{3}{|c|}{ Loan $=1$} & \multicolumn{3}{|c|}{ Loan $=0$} & \multirow[b]{2}{*}{$p$-value } \\
\hline & mean & s.d. & $\mathrm{N}$ & mean & s.d. & $\mathrm{N}$ & \\
\hline Hours for Networking & 3.66 & 1.81 & 113 & 3.30 & 1.77 & 136 & 0.11 \\
\hline Hospitality Expenses & 1.04 & 0.78 & 110 & 0.90 & 0.80 & 134 & 0.17 \\
\hline $\begin{array}{l}\text { Business } \\
\text { Associations }\end{array}$ & 0.81 & 0.39 & 121 & 0.70 & 0.46 & 148 & 0.04 \\
\hline Communist & 0.37 & 0.48 & 111 & 0.30 & 0.46 & 140 & 0.25 \\
\hline
\end{tabular}

Panel B: Loan from State Banks

\begin{tabular}{lccccccc}
\hline & \multicolumn{6}{c}{ State Bank Loan = 1 } & \multicolumn{7}{c}{ State Bank Loan = 0 } \\
\hline & Mean & s.d. & $\mathrm{N}$ & mean & s.d. & $\mathrm{N}$ & p-value \\
\hline Hours for Networking & 3.43 & 1.86 & 72 & 3.48 & 1.77 & 177 & 0.85 \\
Hospitality Expenses & 0.99 & 0.78 & 68 & 0.96 & 0.80 & 176 & 0.73 \\
Business & 0.82 & 0.39 & 76 & 0.73 & 0.45 & 193 & 0.10 \\
Associations & & & & & & & \\
Communist & 0.39 & 0.49 & 69 & 0.31 & 0.46 & 182 & 0.22 \\
\hline
\end{tabular}

Panel C: Loans from Local Commercial Banks

\begin{tabular}{|c|c|c|c|c|c|c|c|}
\hline & \multicolumn{3}{|c|}{ Commercial Bank Loan $=1$} & \multicolumn{3}{|c|}{ Commercial Bank Loan $=0$} & \multirow[b]{2}{*}{$p$-value } \\
\hline & mean & s.d. & $\mathrm{N}$ & mean & s.d. & $\mathrm{N}$ & \\
\hline Hours for Networking & 4.15 & 1.85 & 54 & 3.28 & 1.74 & 195 & 0.00 \\
\hline Hospitality Expenses & 1.11 & 0.77 & 55 & 0.93 & 0.80 & 189 & 0.13 \\
\hline $\begin{array}{l}\text { Business } \\
\text { Associations }\end{array}$ & 0.82 & 0.39 & 60 & 0.73 & 0.44 & 209 & 0.15 \\
\hline Communist & 0.34 & 0.48 & 56 & 0.33 & 0.47 & 195 & 0.88 \\
\hline
\end{tabular}

Note: $p$-value is the $p$-value of $T$ test of equality of means of two groups. 
Table 4: Logit Results with Hours for Networking as a Measure of Social Capital.

\begin{tabular}{lccc}
\hline & All & State & Commercial \\
& $(1)$ & $(2)$ & $(3)$ \\
\hline Female & 0.018 & 0.060 & -0.031 \\
Hours for Networking & $(0.098)$ & $(0.070)$ & $(0.070)$ \\
& 0.023 & -0.004 & $0.037^{* *}$ \\
Lagged ROS & $(0.021)$ & $(0.013)$ & $(0.015)$ \\
& $0.458^{* *}$ & $0.231^{* *}$ & 0.199 \\
Firm Age & $(0.204)$ & $(0.108)$ & $(0.123)$ \\
& -0.005 & 0.004 & -0.009 \\
Log(Labor) & $(0.008)$ & $(0.005)$ & $(0.006)$ \\
& $0.081^{* *}$ & 0.027 & $0.067^{* *}$ \\
Collateral & $(0.039)$ & $(0.022)$ & $(0.030)$ \\
& 0.000 & -0.001 & $0.002^{* *}$ \\
\hline N. Obs. & $(0.001)$ & $(0.001)$ & $(0.001)$ \\
Log Likelihood & 247 & 247 & 247 \\
\hline
\end{tabular}

Note: Dependent variable is dummy variable for having loans. Robust standard errors are in parentheses. Marginal effects estimated around mean points are reported. Constant, industry, region and time dummies are included into specification but not reported. 
Table 5: Logit Results with Hospitality Expenses as a Measure of Social Capital.

\begin{tabular}{lccc}
\hline & All & State & Commercial \\
& $(1)$ & $(2)$ & $(3)$ \\
\hline Female & -0.015 & 0.054 & -0.077 \\
Hospitality Expenses & $(0.101)$ & $(0.076)$ & $(0.070)$ \\
& 0.018 & -0.016 & 0.026 \\
Lagged ROS & $(0.045)$ & $(0.029)$ & $(0.034)$ \\
& $0.458^{* *}$ & $0.272^{* *}$ & 0.201 \\
Firm Age & $(0.200)$ & $(0.114)$ & $(0.127)$ \\
& -0.003 & 0.003 & -0.007 \\
Log(Labor) & $(0.008)$ & $(0.005)$ & $(0.007)$ \\
& 0.063 & 0.030 & 0.050 \\
Collateral & $(0.041)$ & $(0.025)$ & $(0.032)$ \\
& 0.001 & -0.001 & $0.002^{*}$ \\
\hline Obs. & $(0.001)$ & $(0.001)$ & $(0.001)$ \\
Log Likelihood & 243 & 243 & 243 \\
\hline
\end{tabular}

Note: Dependent variable is dummy variable for having loans. Robust standard errors are in parentheses. Marginal effects estimated around mean points are reported. Constant, industry, region, and time dummies are included into specification but not reported. 
Table 6: Logit results with Associations as a measure of Social Capital.

\begin{tabular}{lccc}
\hline & All & State & Commercial \\
& $(1)$ & $(2)$ & $(3)$ \\
\hline Female & -0.024 & 0.041 & -0.062 \\
Associations & $(0.095)$ & $(0.068)$ & $(0.061)$ \\
& $0.148^{* *}$ & 0.060 & $0.096^{*}$ \\
Lagged Ros & $(0.072)$ & $(0.043)$ & $(0.049)$ \\
& $0.508^{* * *}$ & $0.269^{* *}$ & $0.254^{* *}$ \\
Firm Age & $(0.196)$ & $(0.111)$ & $(0.123)$ \\
& -0.008 & 0.002 & $-0.012^{*}$ \\
Log(Labor) & $(0.008)$ & $(0.005)$ & $(0.006)$ \\
& $0.064^{*}$ & 0.024 & $0.054^{*}$ \\
Collateral & $(0.038)$ & $(0.022)$ & $(0.029)$ \\
& 0.001 & -0.001 & $0.002^{* *}$ \\
\hline Obs. & $(0.001)$ & $(0.001)$ & $(0.001)$ \\
Log Likelihood & 269 & 269 & 269 \\
\hline
\end{tabular}

Note: Dependent variable is dummy variable for having loans. Robust standard errors are in parentheses. Marginal effects estimated around mean points are reported. Constant, industry, region, and time dummies are included into specification but not reported. 
Table 7: Logit Results with Communist as a Measure of Social Capital.

\begin{tabular}{lccc}
\hline & All & State & Commercial \\
& $(1)$ & $(2)$ & $(3)$ \\
\hline Female & 0.039 & 0.112 & -0.067 \\
Communist & $(0.100)$ & $(0.083)$ & $(0.066)$ \\
& 0.092 & $0.102^{* *}$ & -0.032 \\
Lagged ROS & $(0.071)$ & $(0.051)$ & $(0.052)$ \\
& $0.504^{* *}$ & $0.263^{* *}$ & $0.206^{*}$ \\
Firm Age & $(0.197)$ & $(0.108)$ & $(0.124)$ \\
& -0.001 & 0.006 & -0.009 \\
Log(Labor) & $(0.008)$ & $(0.005)$ & $(0.006)$ \\
& $0.073^{*}$ & 0.019 & $0.070^{* *}$ \\
Collateral & $(0.038)$ & $(0.022)$ & $(0.031)$ \\
& 0.000 & -0.001 & $0.002^{* *}$ \\
\hline Obs. & $(0.001)$ & $(0.001)$ & $(0.001)$ \\
Pseudo-R2 & 251 & 251 & 251 \\
\hline
\end{tabular}

Note: Dependent variable is dummy variable for having loans. Robust standard errors are in parentheses. Marginal effects estimated around mean points are reported. Constant, industry, region, and time dummies are included into specification but not reported. 